University of Nebraska - Lincoln

DigitalCommons@University of Nebraska - Lincoln

USDA National Wildlife Research Center - Staff Publications
U.S. Department of Agriculture: Animal and Plant Health Inspection Service

2010

\title{
Acute toxicity of diphacinone in Northern bobwhite: Effects on survival and blood clotting
}

\author{
Barnett A. Rattner \\ Patuxent Wildlife Research Center, brattner@usgs.gov \\ Katherine E. Horak \\ USDA/APHIS/WS National Wildlife Research Center, katherine.e.horak@aphis.usda.gov \\ Sarah E. Warner \\ Patuxent Wildlife Research Center, sarah_warner@fws.gov \\ John J. Johnston \\ National Wildlife Research Center
}

Follow this and additional works at: https://digitalcommons.unl.edu/icwdm_usdanwrc

Part of the Life Sciences Commons

Rattner, Barnett A.; Horak, Katherine E.; Warner, Sarah E.; and Johnston, John J., "Acute toxicity of diphacinone in Northern bobwhite: Effects on survival and blood clotting" (2010). USDA National Wildlife Research Center - Staff Publications. 1270.

https://digitalcommons.unl.edu/icwdm_usdanwrc/1270

This Article is brought to you for free and open access by the U.S. Department of Agriculture: Animal and Plant Health Inspection Service at DigitalCommons@University of Nebraska - Lincoln. It has been accepted for inclusion in USDA National Wildlife Research Center - Staff Publications by an authorized administrator of DigitalCommons@University of Nebraska - Lincoln. 


\title{
Acute toxicity of diphacinone in Northern bobwhite: Effects on survival and blood clotting
}

\author{
Barnett A. Rattner ${ }^{\mathrm{a}, *}$, Katherine E. Horak ${ }^{\mathrm{b}}$, Sarah E. Warner ${ }^{\mathrm{a}}$, John J. Johnston ${ }^{\mathrm{b}}$ \\ a Patuxent Wildlife Research Center, U.S. Geological Survey, Department of the Interior, 10300 Baltimore Avenue, BARC East-308, Beltsville, MD 20705, USA \\ ${ }^{\mathrm{b}}$ National Wildlife Research Center, Animal and Plant Health Inspection Service, U.S. Department of Agriculture, Ft. Collins, CO 80521, USA
}

\section{A R T I C L E I N F O}

\section{Article history:}

Received 24 March 2010

Received in revised form

28 May 2010

Accepted 30 May 2010

Available online 30 June 2010

Keywords:

Anticoagulant

Birds

Clotting time

Diphacinone

Fibrinogen

Non-target effects

Prothrombin time

Russell's Viper venom time

Secondary poisoning

Thrombin clotting time

\begin{abstract}
A B S T R A C T
The anticoagulant rodenticide diphacinone was slightly toxic (acute oral $\mathrm{LD}_{50} 2014 \mathrm{mg} / \mathrm{kg}$ ) to Northern bobwhite (Colinus virginianus) in a 14-day acute toxicity trial. Precise and sensitive assays of blood clotting (prothrombin time, Russell's Viper venom time, and thrombin clotting time) were adapted for use in quail, and this combination of assays is recommended to measure the effects of anticoagulant rodenticides. A single oral sublethal dose of diphacinone $(434 \mathrm{mg} / \mathrm{kg}$ body weight) prolonged clotting time at $48 \mathrm{~h}$ post-dose compared to controls. At $783 \mathrm{mg} / \mathrm{kg}$ (approximate $\mathrm{LD}_{02}$ ), clotting time was prolonged at both 24 and $48 \mathrm{~h}$ post-dose. Prolongation of in vitro clotting time reflects impaired coagulation complex activity, and was detected before overt signs of toxicity were apparent at the greatest dosages $(2868$ and $3666 \mathrm{mg} / \mathrm{kg}$ ) in the acute toxicity trial. These clotting time assays and toxicity data will assist in the development of a pharmacodynamic model to predict toxicity, and also facilitate rodenticide hazard and risk assessments in avian species.
\end{abstract}

Published by Elsevier Inc.

\section{Introduction}

Public concern over poisoning of non-target wildlife began in the early 20th century when strychnine and thallium used for rodent and predator control were observed to be affecting species like quail and song birds (Peterle, 1991). In the 1930s, Link investigated the hemorrhagic effects of improperly cured sweet clover (Melilotus spp.) in domestic livestock, and eventually isolated 3,3'-methylene-bis(4-hydroxycoumarin) (i.e., dicumarol) (Pelfrene, 1991). This discovery ultimately led to the synthesis of over 100 analogs, including warfarin that was eventually used as a rodenticide. The mechanism of action of warfarin, and other anticoagulant rodenticides, involves inhibition of synthesis of functional vitamin K-dependent factors including prothrombin.

Several current use anticoagulant rodenticides pose hazard to ground feeding birds by direct ingestion of bait (primary poisoning) and to predatory and scavenging birds by consumption of poisoned rodents or exposed invertebrate prey (secondary poisoning). Non-target exposure and effects of anticoagulant rodenticides in wildlife have been documented in many countries,

\footnotetext{
* Corresponding author. Fax: +1 3014975624 .

E-mail address: brattner@usgs.gov (B.A. Rattner).
}

including the United States, United Kingdom, France, Canada, Malaysia and New Zealand (e.g., Albert et al., 2009; Eason and Spurr, 1995; Howald et al., 1999; Lambert et al., 2007; Stone et al., 1999, 2003; Walker et al., 2008). For example, in New York State there were at least 51 confirmed cases of death by hemorrhage with detection of rodenticides in tissues of wildlife between 1971 and 1997, with over half of the incidents involving birds of prey (e.g., great horned owl, Bubo virginianus; red-tailed hawk, Buteo jamaicensis) (Stone et al., 1999). Based on these findings, an anticoagulant surveillance program was implemented between 1998 and 2001 for routine avian submissions to the New York State Wildlife Pathology Unit. Remarkably, 49\% of 265 raptors had detectable quantities of anticoagulants in liver tissue, and anticoagulants were considered the cause of death in nearly $15 \%$ of these cases (Stone et al., 2003). On a global scale, the magnitude of the hazard of rodenticides to birds is not well-characterized because the effect of sublethal exposure on long-term survival and fitness is unknown, and most lethal poisoning events are probably unnoticed or not reported.

In 2002, the US Environmental Protection Agency (US EPA) completed a risk assessment that identified several rodenticides that posed a significant risk to birds and non-target mammals (Erickson and Urban, 2004). Subsequently, the US EPA (2008) released its final ecological risk mitigation decision that placed 


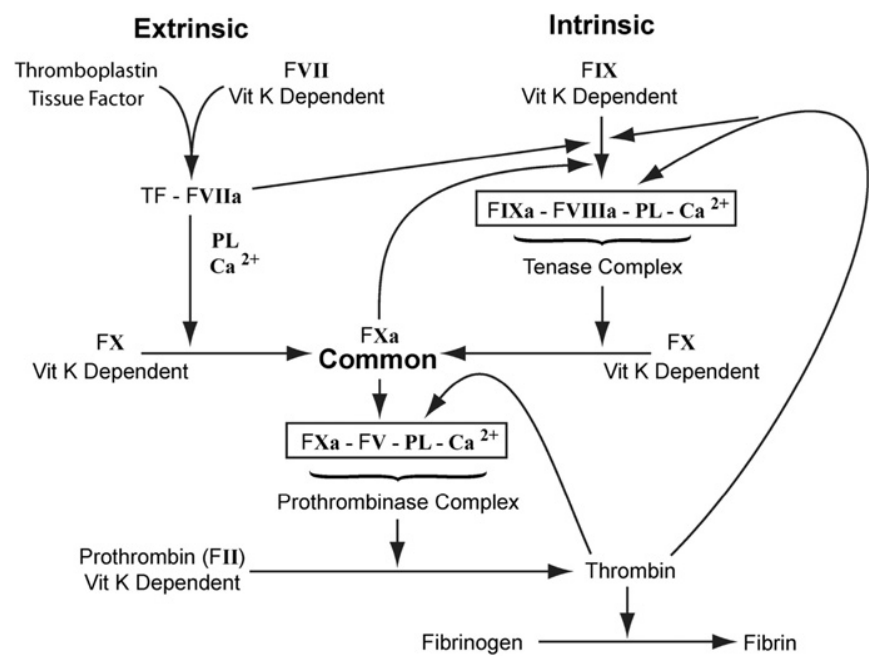

Fig. 1. Blood coagulation pathway in birds (adapted from Gentry, 1993 and Thomson et al., 2002; $F=$ Factor, $\mathrm{PL}=$ phospholipid).

some restrictions on the sale, distribution and packaging of several second generation rodenticides (i.e., brodifacoum, difethialone, bromadiolone and difenacoum) that have greater toxicity and are more persistent in tissues than first generation rodenticides. This action will likely be offset by expanded use of other anticoagulant rodenticides, including diphacinone (classified as a first or intermediate generation compound). Unfortunately, the hazard posed by diphacinone to non-target organisms is inadequately characterized. Median lethal dosages, sublethal responses and tissue concentrations are being generated in both traditional wildlife test species (e.g., Northern bobwhite, Colinus virginianus) and in birds of prey that are occasionally used in toxicity tests (e.g., American kestrels, Falco sparverius and Eastern screech owls, Megascops asio) (Rattner et al., 2010). Various measurement endpoints are being used to develop a physiologically based pharmacokinetic model (PBPK) that will facilitate estimation of diphacinone burdens and risk to avian species. One endpoint critical to this effort is the measurement of blood clotting time. The effects of anticoagulant rodenticides on hemostasis are better characterized in mammals than in birds. This may be attributable to several factors including greater societal concerns for humans, domesticated and companion mammals, inter-specific differences in blood clotting pathways that influence coagulation testing (Fig. 1; Powers, 2000; Thomson et al., 2002) and limited commercial availability of reagents and controls optimized for use in birds. As an initial step in determining the toxicity of diphacinone to avian species, blood clotting assays were adapted for use in bobwhite. Hopefully, such diphacinone toxicity data and the PBPK model will assist in selection of efficacious baiting strategies that may mitigate risk to non-target species.

\section{Methods}

\subsection{Animals and diphacinone dosing}

Animal procedures were approved by the Institutional Animal Care and Use Committees of the National Wildlife Research Center (NWRC), Animal and Plant Health Inspection Service of the US Department of Agriculture (USDA) and the Patuxent Wildlife Research Center (PWRC), US Geological Survey (USGS) of the Department of the Interior. Adult Northern bobwhite were obtained from $R$ \& $R$ Game Birds (Lamar, CO), and housed individually in indoor pens $\left(61 \times 46 \times 33 \mathrm{~cm}^{3}\right.$ high) at NWRC. Bobwhite quail were maintained in a $12 \mathrm{~h}$ light: $12 \mathrm{~h}$ dark photoperiod at $18-21^{\circ} \mathrm{C}$, and provided food (Purina Game Bird Maintenance Chow $®$ Product 5440, 12.5\% protein, Denver, CO) and water ad libitum.
An acute oral toxicity study was conducted in bobwhite (weight range: 149-224 g) gavaged with technical grade diphacinone (99\% active ingredient; Hacco, Inc. Randolph, WI) suspended in pure vegetable oil (soybean oil cholesterol-free; Crisco $($, Orrville, $\mathrm{OH})$. The selection of doses was somewhat problematic as existing data suggested that the slope of the dose-response curve was steep, and doses were too widely separated to permit estimation of a reliable median lethal dose (Campbell et al., 1991; US EPA, 1998). Accordingly, the study was conducted over a six week period using analytically determined diphacinone doses that were selected through an iterative process $(917,965,1033,2065,2868$ and $3666 \mathrm{mg} / \mathrm{kg}$ body weight; $n=9-10$ bobwhite/dose; approximately equal distribution of sexes/dose). Because of low solubility, diphacinone was administered as slurry in vegetable oil (heaviest bird in a dose group received $1 \mathrm{ml}$ and the remaining birds received a fractional volume related to their weight $0.76-0.99 \mathrm{ml}$ ). Some target doses could only be achieved by repeatedly administering a divided dose over a 24-h period (target exposure of 1033 and $2065 \mathrm{mg} / \mathrm{kg}$ : 2 doses/day; target exposure of $2868 \mathrm{mg} / \mathrm{kg}$ : 3 dose/day and target exposure of $3666 \mathrm{mg} / \mathrm{kg}$ : 4 doses/day). Moderate volumes of the vehicle were also administered 1-3 times to controls ( $n=9$ ) during a 24-h period. Birds were observed twice daily for signs of toxicity over a 14-day period.

Based upon the results of this acute toxicity trial, a second study was conducted in which bobwhite (weight range: 178-241 g) were gavaged with either vegetable oil (control $n=6$ ), or with analytically determined doses of diphacinone at $434 \mathrm{mg} / \mathrm{kg}(n=16)$ or $783 \mathrm{mg} / \mathrm{kg}(n=16)$. At $6,12,24$ and $48 \mathrm{~h}$ post-dose, each bird was euthanized with carbon dioxide and immediately bled by cardiac puncture. Controls were sacrificed and bled at $48 \mathrm{~h}$ post-dose. Blood samples $(0.5 \mathrm{ml})$ were collected into syringes containing $50 \mu \mathrm{l} 0.5 \mathrm{M}$ EDTA, a suitable alternative to sodium citrate (Cerón et al., 2008). Blood samples were centrifuged, plasma harvested and frozen at $-80^{\circ} \mathrm{C}$, and subsequently shipped to the PWRC for analysis.

\subsection{Analytical determination of diphacinone in dosing solutions}

For determination of diphacinone concentration in dosing solutions, $100 \mu \mathrm{l}$ of the slurry was weighed and dissolved in $10 \mathrm{ml}$ of $1: 1$ acetone:chloroform, and $10 \mu \mathrm{l}$ was diluted to $10 \mathrm{ml}$ with $5 \mathrm{mM}$ tetrabutylammonium phosphate in $12 \mathrm{mM}$ phosphate buffer ( $\mathrm{pH} 8.5$ ) and methanol (40:60 ratio). The sample was placed in an ultrasonic bath for $5 \mathrm{~min}$, filtered through a $0.45 \mu \mathrm{m}$ teflon syringe filter into an amber vial, and analyzed by reverse phase ion-paired high-performance liquid chromatography with concentrations determined by comparison to a calibration standard (Primus et al., 1996). The method detection limit was $4 \mathrm{ng} / \mathrm{ml}$ and the precision (mean coefficient of variation \pm standard deviation) for triplicate determinations was $3.3 \pm 1.5 \%(n=3)$.

\subsection{Clotting assays}

One-stage prothrombin time, Russell's Viper venom time, and thrombin clotting time were measured in plasma samples using a thermostatically controlled BBL fibrometer (Becton Dickson \& Co., Baltimore, MD) (Miale, 1965). Upon addition of reagents and plasma into a sample cup, a clot detection arm with a stationary electrode and a moving electrode automatically drop into the cup, and the formation of a fibrin clot between the electrodes (measurement endpoint) is determined by a detection circuit linked to a timer.

\subsubsection{One-stage prothrombin time assay}

In this assay, an excess of tissue factor and phospholipid (thromboplastin) interacts with plasma Factor VII to form an active complex, and through a cascade of subsequent reactions (Factor $\mathrm{X}$ activation, conversion of prothrombin to thrombin) fibrinogen is eventually converted to fibrin which forms the clot (Fig. 1). Crude chicken hatchling thromboplastin was prepared by the method of Quick as modified by Griminger et al. (1970) and Doerr et al. (1975). The cerebral cortex of 3-day old broiler chicks (Gallus gallus) was removed, weighed and homogenized in 10 volumes of cold acetone. This suspension was centrifuged at $1500 \mathrm{~g}$ for $10 \mathrm{~min}$, and the supernatant was discarded. The pellet was re-suspended in $5 \mathrm{ml}$ of acetone, homogenized, centrifuged, acetone decanted, and this procedure was repeated. The pellet was then re-suspended in acetone, vacuum filtered using a Büchner funnel with a glass microfiber filter (Whatman 934-AH, $1.5 \mu \mathrm{m}$ retention, Fisher Scientific, Suwanee, GA). The material retained on the filter was dried over night in a vacuum desiccator, removed from the microfiber filter, ground with a mortar and pestle, and transferred into cryotubes which were frozen at $-80^{\circ} \mathrm{C}$.

For the one-stage prothrombin time assay, $50 \mathrm{mg}$ of the crude chicken hatchling thromboplastin (CHT) was suspended in $2500 \mu \mathrm{l}$ of $25 \mathrm{mM} \mathrm{CaCl}_{2}$, and incubated at $42{ }^{\circ} \mathrm{C}$ for $15 \mathrm{~min}$ with intermittent vortexing. This suspension was centrifuged at $1500 \mathrm{~g}$ for $20 \mathrm{~min}$, and the supernatant was further diluted (1:1) with $25 \mathrm{mM} \mathrm{CaCl}_{2}$ (final concentration $\sim 220 \mu \mathrm{g}$ protein $/ \mathrm{ml}, \mathrm{BCA}^{\mathrm{TM}}$ Protein Assay Kit, Pierce, Rockford, IL). Plasma $(100 \mu \mathrm{l})$ was incubated at $37{ }^{\circ} \mathrm{C}$ in a sample cup for $2 \mathrm{~min}$, and the reaction was initiated with the addition of $200 \mu \mathrm{l}$ of the CHT. Samples were generally analyzed in duplicate, and the performance of the fibrometer was routinely checked using human plasma reference standards 
incubated with Simplastin $($ (rabbit brain thromboplastin; Trinity Biotech, Berkeley Heights, NJ). Intra-assay precision (mean coefficient of variation \pm standard deviation) for duplicate determinations of bobwhite plasma with CHT was $4.6 \pm 4.5 \%(n=30)$. Inter-assay precision over the course of a year for human reference samples using Simplastin $\AA$ was $2.9 \pm 2.2 \%(n=13)$. When the CHT solution was diluted, clotting time of bobwhite plasma was found to increase (Fig. 2). When bobwhite plasma was diluted with $8.3 \mathrm{mM}$ sodium potassium phosphate buffer ( $\mathrm{pH} 7.2$ ), clotting time was relatively stable at plasma dilutions ranging between $40 \%$ and $80 \%$, but increased dramatically at dilutions containing less than $20 \%$ plasma (Fig. 3 ).

\subsubsection{Russell's Viper venom time (RVVT)}

In this assay, Russell's Viper venom (RVV) directly activates Factor X (but not Factor VII) in the common pathway of the clotting cascade (Fig. 1). Reconstituted RVV Factor X activator (American Diagnostica, Stamford, CT) was diluted 1:10 with imidazole buffered saline (IBS; $0.0125 \mathrm{M}$ imidazole $0.109 \mathrm{M} \mathrm{NaCl}, \mathrm{pH} 7.4$ ) and maintained at room temperature. Plasma $(100 \mu \mathrm{l})$ was incubated at $37^{\circ} \mathrm{C}$ in a sample cup for $2 \mathrm{~min}$, and $100 \mu \mathrm{l}$ of diluted RVV was added to the sample cup and incubated for $15 \mathrm{~s}$. The clotting reaction was initiated with $100 \mu \mathrm{l} 25 \mathrm{mM} \mathrm{CaCl}_{2}$, and time to clot was measured (Triplett and Harms, 1981a). Intra-assay precision for duplicate determinations of bobwhite plasma was $6.5 \pm 13.5 \%(n=19)$. Clotting time remained relatively stable when bobwhite plasma was diluted by as much as $60 \%$ with phosphate buffer, but RVVT increased dramatically at greater dilutions (Fig. 4).

\subsubsection{Thrombin clotting time (TCT)}

This assay measures the time for conversion of fibrinogen to fibrin (Fig. 1) using a standard thrombin solution (Triplett and Harms, 1981b). This assay is

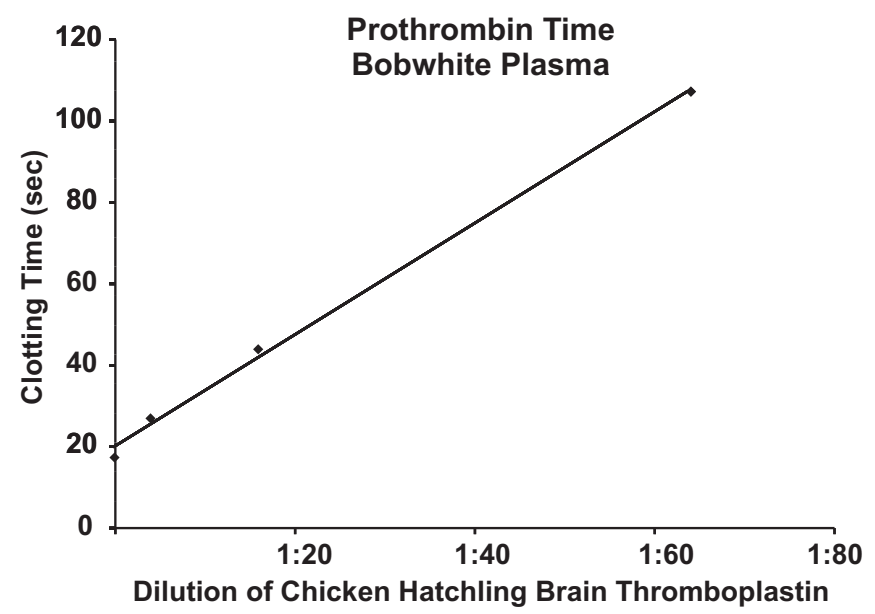

Fig. 2. Clot promoting potential of undiluted $(0)$ and diluted $(1: 4,1: 16$ and 1:64) chicken hatchling thromboplastin incubated with bobwhite plasma. Prothrombin time increased linearly as thromboplastin was diluted $(p<0.01$; prothrombin time $=19.9+1.38$ (thromboplastin dilution); $R^{2}=0.99$ ).

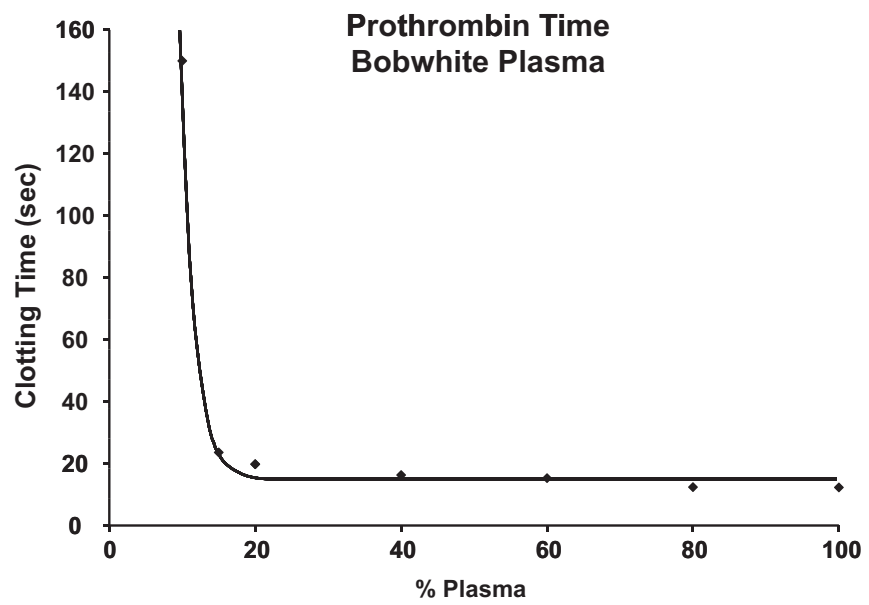

Fig. 3. Effect of diluting bobwhite plasma (100\%, $80 \%, 60 \%, 40 \%, 20 \%, 15 \%$ and $10 \%$ plasma) with phosphate buffer on prothrombin time (prothrombin time $=$ $\left.15.0+29158 \mathrm{e}^{-0.54(\% \text { plasma })} ; R^{2}=0.99\right)$.

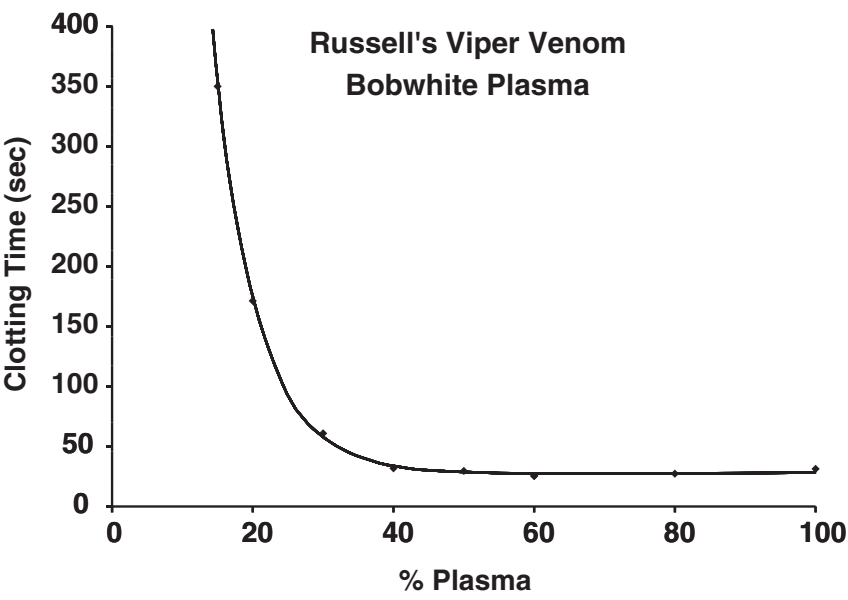

Fig. 4. Effect of diluting bobwhite plasma (100\%, $80 \%, 60 \%, 50 \%, 40 \%, 30 \%, 20 \%$ and $15 \%$ plasma) with phosphate buffer on Russell's Viper venom clotting time $\left(\right.$ RVVT $\left.=28.0+3514 \mathrm{e}^{-0.16(\% \text { plasma })} ; R^{2}=0.99\right)$.

insensitive to deficiency of vitamin K-dependent clotting factors but is an indicator of the amount of fibrinogen in the plasma sample. Fibrinogen deficiency from improper sample collection and handling can prolong prothrombin time and RVVT, and thus affect test method accuracy (increase false positive rate). For this heterologous assay, bovine thrombin reagent and human fibrinogen reference material was used (AMAX Fibrinogen kit, Trinity Biotech). A fibrinogen standard curve was prepared (65-520 mg/dL), and bobwhite plasma samples were diluted 1:10 with IBS. Diluted plasma $(200 \mu \mathrm{l})$ was incubated at $37{ }^{\circ} \mathrm{C}$ in a sample cup for $2 \mathrm{~min}$, and the reaction initiated by the addition of $100 \mu \mathrm{l}$ of thrombin reagent. Clotting time of the test sample is transformed to fibrinogen concentration $(\mathrm{mg} / \mathrm{dL})$ from the fibrinogen standard curve. Intra-assay precision for duplicate determinations of bobwhite plasma was $5.7 \pm 6.8 \%(n=32)$.

\subsection{Statistical methods}

For the acute toxicity trial, the relation between diphacinone dose and survival, and estimates of the slope, median lethal dose $\left(\mathrm{LD}_{50}\right)$ and $95 \%$ confidence interval were determined using the probit analysis procedure in SAS (SAS Institute, Carey, NC). In the sublethal dosing study, prothrombin time, RVVT and TCT measurement endpoints were tested for homogeneity of variance (Fmax test) and normality (Shapiro-Wilk test, normal probability plot and descriptive statistics). Homogeneity of variance and normality were improved following log-transformation, and measurement endpoints were then compared by analysis of variance (ANOVA) and a Tukey's HSD test. A regression ANOVA was used to examine the relation between prothrombin time and dilution of the CHT. A one-phase decay model (Prism, GraphPad Software, Inc., La Jolla, CA) was used to describe the relation between clotting time and dilution of bobwhite plasma in the prothrombin time and RVVT assays.

\section{Results}

\subsection{Acute and sublethal toxicity studies}

Survival of bobwhite was significantly related $(p<0.0001)$ to dose of diphacinone ( 9 of 10 survivors at $917 \mathrm{mg} / \mathrm{kg}, 8$ of 9 at $965 \mathrm{mg} / \mathrm{kg}, 10$ of 10 at $1033 \mathrm{mg} / \mathrm{kg}, 7$ of 10 at $2065 \mathrm{mg} / \mathrm{kg}, 1$ of 10 at $2868 \mathrm{mg} / \mathrm{kg}$ and 0 of 10 at $3666 \mathrm{mg} / \mathrm{kg}$ ), with most of the birds receiving greatest doses ( 2868 and $3666 \mathrm{mg} / \mathrm{kg}$ ) dying within 1-3 days of exposure. Some of the dosed bobwhite seemed lethargic, and had fluffed feathers. Several of the birds that succumbed had subcutaneous bruises in the breast and back regions, which could reflect coagulopathy; however, there was no evidence of frank internal or external bleeding. Controls that had been dosed multiple times with vehicle in a $24 \mathrm{~h}$ period did not exhibit overt signs of toxicity. The $\mathrm{LD}_{50}$ was estimated to be $2014 \mathrm{mg} / \mathrm{kg}$ (95\% confidence interval $1620-2475 \mathrm{mg} / \mathrm{kg}$ ), and the slope of the dose-response curve was steep (probit/ $/ \log _{10} \pm$ standard error $=9.92 \pm 2.27$ ). 
Based on this dose-response curve, the $783 \mathrm{mg} / \mathrm{kg}$ dose in the sublethal trial falls in the $\mathrm{LD}_{01}-\mathrm{LD}_{02}$ range, and the $434 \mathrm{mg} / \mathrm{kg}$ dose is just slightly greater than the lower $95 \%$ confidence limit of the $\mathrm{LD}_{01}$. All bobwhite receiving these doses survived and did not exhibit overt signs of toxicity.

\subsection{Clotting time}

Administration of 434 and $783 \mathrm{mg}$ diphacinone/kg body weight prolonged clotting time when compared to controls, but the temporal response was highly variable (Figs. 5 and 6). However, the fibrinogen concentration in 5 samples was undetectable, and the volume was too small to determine fibrinogen concentration in another sample. The absence of fibrinogen in these 5 samples suggests that they may have been collected improperly (viz., cardiac puncture of euthanized birds, blood sample partially clotted). Fibrinogen is generally in great excess, and its cleavage to fibrin in the TCT assay is not influenced by vitamin $\mathrm{K}$ antagonists. When these 6 samples were excluded,

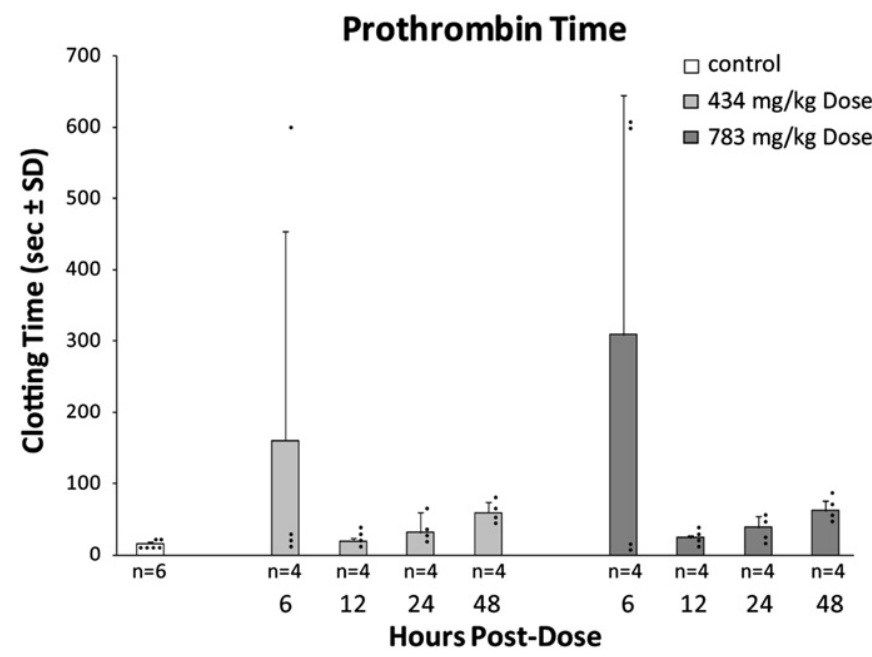

Fig. 5. Prothrombin time (mean \pm standard deviation; $\cdot=$ data point) of all bobwhite gavaged with vehicle (control) or diphacinone $(6,12,24$ and $48 \mathrm{~h}$ post-dose).

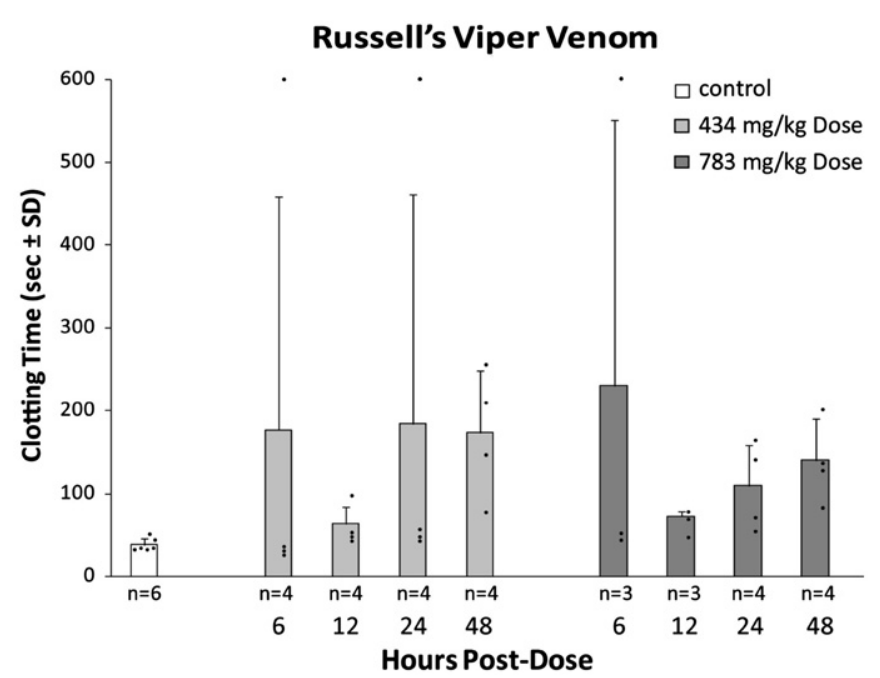

Fig. 6. Russell's Viper venom time (mean \pm standard deviation; $\cdot=$ data point) of all bobwhite gavaged with vehicle (control) or diphacinone $(6,12,24$ and $48 \mathrm{~h}$ post-dose).

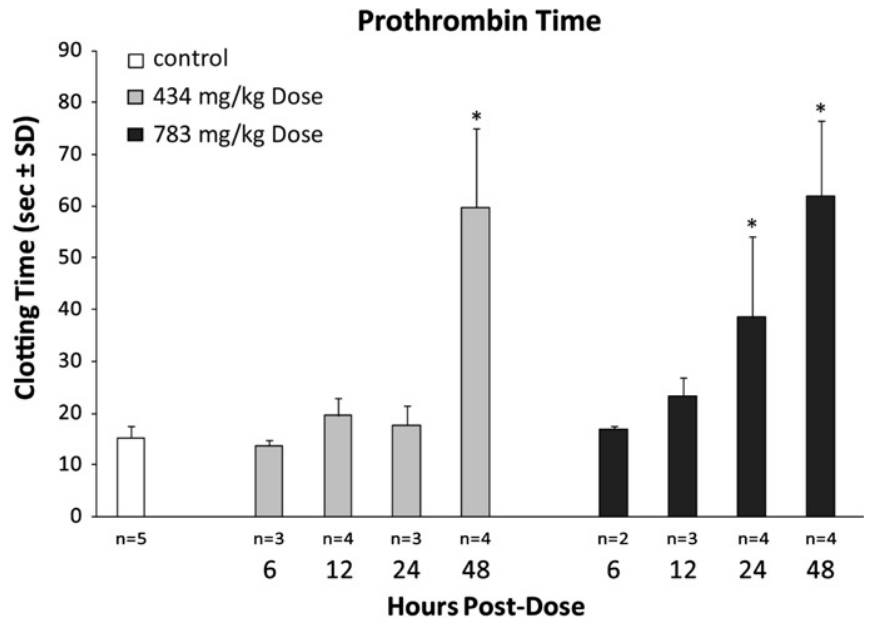

Fig. 7. Prothrombin time (mean \pm standard deviation) of bobwhite gavaged with vehicle (control) or diphacinone $(6,12,24$ and $48 \mathrm{~h}$ post-dose) with plasma fibrinogen $>60 \mathrm{mg} / \mathrm{dL} .{ }^{*}=$ significantly different $(p<0.05)$ than control.

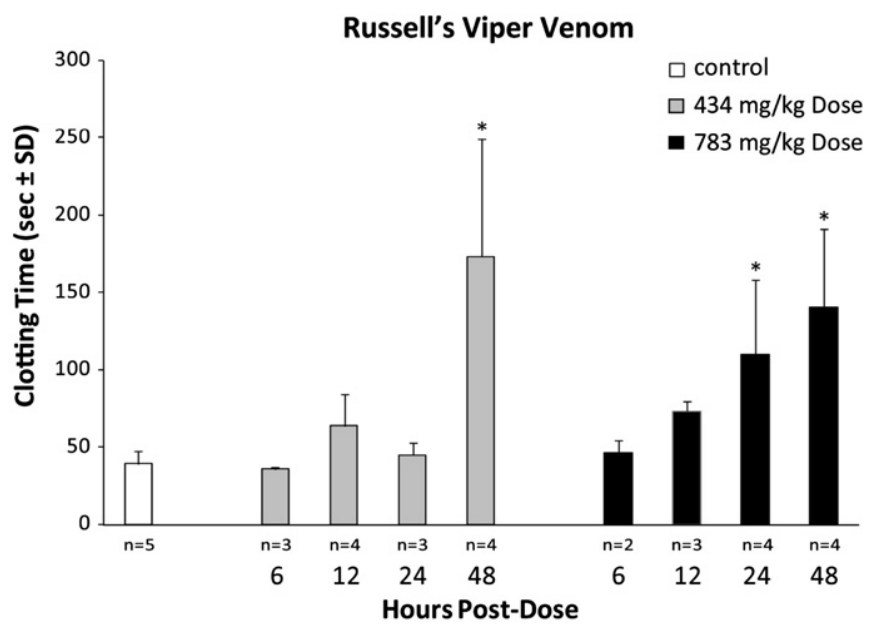

Fig. 8. Russell's Viper venom time (mean \pm standard deviation) of bobwhite gavaged with vehicle (control) or diphacinone $(6,12,24$ and 48 h post-dose) with plasma fibrinogen $>60 \mathrm{mg} / \mathrm{dL} . *=$ significantly different $(p<0.05)$ than control.

all remaining samples $(n=32)$ contained more than $60 \mathrm{mg}$ fibrinogen/dL plasma (range: 63-254 mg/dL). For these remaining samples, prothrombin time (Fig. 7) and RVVT (Fig. 8) were prolonged $(p<0.05$; factors of 3.9 and 4.4$)$ at $48 \mathrm{~h}$ after administration of $434 \mathrm{mg} / \mathrm{kg}$ when compared to the control group. Following administration of diphacinone at $783 \mathrm{mg} / \mathrm{kg}$, prothrombin time and RVVT were prolonged at both $24 \mathrm{~h}$ $(p<0.05$; factors of 2.5 and 2.8$)$ and $48 \mathrm{~h}(p<0.05$, factors of 4.1 and 3.6) when compared to the control group.

\section{Discussion}

Using categories of toxicity that describe harm (Loomis, 1978), results of the 14-day acute toxicity test suggest that diphacinone may be classified as only slightly toxic $\left(\mathrm{LD}_{50} 2014 \mathrm{mg} / \mathrm{kg}\right)$ to Northern bobwhite. In a previous study (Campbell et al., 1991), a reliable median lethal dose for diphacinone in bobwhite could not be estimated (dosing concentrations were separated by a factor of $5)$, although inspection of the data suggest that the theoretical value fell between 400 and $2000 \mathrm{mg} / \mathrm{kg}$ (US EPA, 1998). Our estimated $\mathrm{LD}_{50}$ in bobwhite is within the same order of 
magnitude as that reported in mallards (Anas platyhrynchos; $3158 \mathrm{mg} / \mathrm{kg}$ ) (Erikson and Urban, 2004). Based upon these data, technical grade diphacinone appears to be considerably less toxic to birds than to laboratory rats (range of estimated $\mathrm{LD}_{50}$ $1.9-7 \mathrm{mg} / \mathrm{kg})$, domesticated mammals $(0.8-15 \mathrm{mg} / \mathrm{kg})$, and wild mammals $(0.2-340 \mathrm{mg} / \mathrm{kg}$ ) (reviewed in Eisemann and Swift, 2006; Erikson and Urban, 2004). Accordingly, diphacinone baits or environmental residues would seemingly present a reduced hazard to birds compared to mammals. Nonetheless, it has been linked to secondary poisoning in raptors (Stone et al., 1999, 2003). Furthermore, results of a recent 7-day acute oral toxicity study in American kestrels ( $F$. sparverius) found diphacinone to be moderately toxic ( $\mathrm{LD}_{50} 97 \mathrm{mg} / \mathrm{kg}$ ) (Rattner et al., 2010), suggesting that extrapolation of diphacinone toxicity from Northern bobwhite and mallards to other avian orders (e.g., Falconiformes, Stringiformes) may be dubious, and protection of raptors may require substantial safety factors.

Three coagulation assays were adapted that yielded short and precise clotting times with EDTA-treated plasma from bobwhite. Using a thromboplastin extract from chicken hatchlings, prothrombin time of untreated bobwhite (mean \pm standard deviation: $15.2 \pm 1.5 \mathrm{~s}$, Fig. 7) was in the range of values reported for several species of domesticated birds (chicken; turkey, Meleagris gallopavo; Japanese quail, Coturnix coturnix) and wild birds (e.g., black ducks, Anas supercillosa; American kestrels; Eastern screech owls, M. asio; black kite, Milus migrans; Egyptian vulture, Neophron percnopterus; wedge-tailed eagles, Aquila audax; pigeon, Columba livia; bronzewing pigeons, Phaps chalcoptera; Hispaniolan parrot, Amazona ventralis; umbrella cockatoo, Cacatua alba; Port Lincoln parrots, Barnardius zonarius; Australian magpies, Gymnorhina tibicen) (Martin et al., 1994; Morrisey et al., 2003; reviewed in Powers, 2000; Rattner et al., 2009; Thomson et al., 2002; Webster, 2009). Using RVV that activates Factor X in the common pathway, clotting time of plasma from untreated bobwhite $(39.5 \pm 8.9 \mathrm{~s}$, Fig. 8$)$ was greater than that reported in several avian species ( $\sim 9-21 \mathrm{~s}$; Tahira et al. 1977; Timms, 1977), although precision for duplicate determinations (coefficient of variation $6.5 \%$ ) and the standard deviation of the 5 control samples with $>60 \mathrm{mg}$ fibrinogen/dL seems acceptable. The volume of all plasma samples analyzed in the one-stage prothrombin time and RVVT assays was $100 \mu$ l, although dilution curves (Figs. 3 and 4 ) suggest that reagent incubation conditions permit much smaller volumes with only minimal effects on clotting time. Similar findings have been reported for prothrombin time assays in chicken (Bailey et al., 2005) and Japanese quail (Webster, 2009), and by using dilution curves, one could normalize clotting time of samples of variable volumes to a constant volume (e.g., $100 \mu \mathrm{l}$ ) (Bailey et al., 2005).

Anticoagulant rodenticides inhibit vitamin K-dependent posttranslational processing of clotting Factors II (prothrombin), VII, IX and X (reviewed in Powers, 2000), but do not affect the synthesis of fibrinogen. Fibrinogen deficiency resulting from pathophysiologic conditions (e.g., hepatic synthetic failure, disseminated intravascular coagulation, fluid resuscitation after massive blood loss) or from improper sample collection practices can prolong in vitro clotting time. To date, avian studies examining anticoagulant rodenticide toxicity have failed to determine if sample fibrinogen content supports in vitro clot formation. Such a fibrinogen concentration threshold is yet to be established for birds, and in the interim, we used $60 \mathrm{mg} / \mathrm{dL}$. Thus, a conservative diagnostic approach for anticoagulant rodenticide laboratory and field studies that evaluate vitamin K-dependent coagulopathies would entail a combination of assays, namely prothrombin time and/or RVVT, plus determination of fibrinogen to rule out any nonspecific influence on clotting time. Shlosberg and Booth (2006) have proposed that prolongation of prothrombin time by more than $25 \%$ is suggestive of anticoagulant exposure. Consideration should be given to standardizing avian thromboplastin preparations (e.g., International Normalized Ratios) and developing reference values for wild birds to facilitate interpretation of field exposure monitoring. In the absence of standardized avian thromboplastin preparations, RVVT offers the advantage of inter-laboratory comparisons as reagents are commercially available. Ideally, exposure should be confirmed by clotting time endpoints, fibrinogen concentration, and analytical detection of anticoagulant residues in blood or tissue.

In the present study, several samples did not contain detectable quantities of fibrinogen, failed to clot in both the one-stage prothrombin time and RVVT assays, and thus, were excluded from our evaluation of the effects of diphacinone on hemostasis. Clotting time of samples with detectable fibrinogen ( $>60 \mathrm{mg} / \mathrm{dL}$ ) was not affected at 6 and $12 \mathrm{~h}$ after administration of diphacinone, but was prolonged at 24 and $48 \mathrm{~h}$ post-dosage. This time course corresponds with, and may precede, the onset of overt toxicity and lethality at high dosage levels used in the acute toxicity study. The lag time between dosing and development of coagulopathy reflects the half-life clearance of functional coagulation factors and the increasing circulation of des-carboxy, dysfunctional factors. Diphacinone's irreversible inhibition of hepatic vitamin $\mathrm{K}$ epoxide reductase impairs post-translational carboxylation of the prothrombin group of serine protease coagulation factors (Factors II, VII, IX and X). Without the addition of a carboxyl group, these factors are unable to assemble on cell surfaces to form active coagulation complexes. Related studies in American kestrel have shown a similar time course for prolonged clotting time following diphacinone administration (peak effect at $48 \mathrm{~h}$ post-dose), and also demonstrated that clotting time returns to control levels by day 7 post-exposure (Rattner et al., 2010). Detection of prolonged prothrombin time is used as an early indicator of anticoagulant rodenticide ingestion in domestic mammals, and prothrombin time is used routinely to monitor coumadin anticoagulant therapy in people (Mount and Feldman, 1983; Spinler et al., 2005). Prolonged prothrombin times have been reported within days of: (1) dietary exposure to diphacinone (American crow, Corvus brachyrhynchos, Massey et al., 1997; golden eagles, Aquila chrysaetos, Savarie et al., 1979), warfarin (chickens, Veltmann et al., 1981) and brodifacoum (Japanese quail, Webster, 2009), (2) repeated gavage with pindone (wedgetailed eagles, bronzewing pigeons, Port Lincoln parrots, black ducks, Australian magpies, Martin et al., 1994) and (3) intravenous injection of warfarin (chickens, Stopforth, 1970). Aside from evoking outright mortality due to hemorrhage, prolonged clotting time constitutes a change in fitness that could affect tolerance to normal physiological events (e.g., blood loss associated with molt) and environmental stressors (e.g., exposure to contaminants that impair hematopoiesis, altered nutritional plane).

\section{Conclusion}

Diphacinone was found to be of low acute oral toxicity to Northern bobwhite, with effects on coagulation detectable at sublethal concentrations. A series of clotting assays were developed and applied for use in bobwhite that are sensitive, precise, inexpensive, linked to the pathogenesis of toxicity (and ultimately mortality), and have applicability as biomarkers in both controlled laboratory studies and field monitoring. Determination of prothrombin time and/or Russell's Viper venom time, plus fibrinogen concentration to exclude nonspecific influences on clotting, is recommended for diagnostic purposes. These findings and assay methods will assist in the development of a pharmacodynamic model to predict toxicity, and also facilitate rodenticide 
hazard and risk assessments of secondary poisoning in avian species.

\section{Acknowledgments}

The authors wish to thank Dr. Marjory B. Brooks (Comparative Coagulation Section, Cornell University) and Dr. John A. Doerr (University of Maryland) for guidance with the development of the clotting time assays, Drs. Thomas M. Primus and Christi Yoder (NWRC, USDA), and Dr. Moira A. McKernan and Rebecca S. Lazarus (PWRC, USGS) for technical assistance with portions of these studies, and Dr. David J. Hoffman (PWRC, USGS) for reviewing a draft of this manuscript. This work was supported by the USDA, USGS and a grant from the California Department of Food and Agriculture Vertebrate Pest Control Research Advisory Committee (agreement 07-0832). Any use of trade, product or firm names is for descriptive purposes only and does not imply endorsement by the US Government.

\section{References}

Albert, C.A., Wilson, L.K., Mineau, P., Trudeau, S., Elliott, J.E., 2009. Anticoagulant rodenticides in three owl species from western Canada, 1988-2003. Arch. Environ. Contam. Toxicol. 58, 451-459.

Bailey, C., Fisher, P., Eason, C.T., 2005. Assessing anticoagulation resistance in rats and coagulation effects in birds using small-volume blood samples. Sci. Conserv. 249

Campbell, S., Hoxter, K.A., Smith, G.J., 1991. Diphacinone technical: an acute oral toxicity study with Northern bobwhite. Wildlife International, Easton, MD. Project No. 284-103. Submitted by Bell Laboratories, Inc, Madison WI. EPA MRID 422452-01. D177986 S417455, Case Number 819047.

Cerón, J.J., Carli, E., Tasca, S., Martinez-Subiela, S., Caldin, M., 2008. Evaluation of EDTA hematology tubes for collection of blood samples for tests of secondary hemostasis in dogs. Am. J. Vet. Res. 69, 1141-1147.

Doerr, J.A., Wyatt, R.D., Hamilton, P.B., 1975. Investigation and standardization of prothrombin times in chickens. Poultry Sci. 54, 969-980.

Eason, C.T., Spurr, E.B., 1995. Review of the toxicity and impacts of brodifacoum on non-target wildlife. N. Z. J. Zool. 22, 371-379.

Eisemann, J.D., Swift, C.E., 2006. Ecological and human health hazards from broadcast application of $0.005 \%$ diphacinone rodenticide baits in native Hawaiian ecosystems. In: Proceedings of the 22nd Vertebrate Pest Conference, pp. 413-433.

Erickson, W., Urban, D., 2004. Potential risks of nine rodenticides to birds and nontarget mammals: a comparative approach, Office of Prevention, Pesticides and Toxic Substances. US EPA, Washington, DC.

Gentry, P.A., 1993. Blood coagulation and hemostasis. In: Reece, W.O. (Ed.), Duke's Physiology of Domestic Animals 11th edition Cornell University Press, NY, pp. 49-63.

Griminger, P., Shum, Y.S., Budowski, P., 1970. Effect of dietary vitamin K on avian brain thromboplastin activity. Poultry Sci. 49, 1681-1686.

Howald, G.R., Mineau, P., Elliott, J.E., Cheng, K.M., 1999. Brodifacoum poisoning of avian scavengers during rat control on a seabird colony. Ecotoxicology 8, 413-447.

Lambert, O., Pouliquen, H., Larhantec, M., Thorin, C., L'Hostis, M., 2007. Exposure of raptors and waterbirds to anticoagulant rodenticides (difenacoum, bromadiolone, coumatetralyl, coumafen, brodifacoum): epidemiological survey in Loire Atlantique (France). Bull. Environ. Contam. Toxicol. 79, 91-94.

Loomis, T.A., 1978. Essentials of Toxicology. Lea \& Febiger, London pp. 245.

Martin, G.R., Kirkpatrick, W.E., King, D.R., Robertson, I.D., Hood, P.J., Sutherland, J.R., 1994. Assessment of the potential toxicity of an anticoagulant, pindone (2-pivalyl-1,3-indandione), to some Australian birds. Wildl. Res. 21, 85-93.

Massey, J.G., Valutis, L., Marzluff, J., Powers, L.V., 1997. The anticoagulant diphacinone's effect on crow prothrombin time. In: Proceedings of the Annual Conference of the Association of Avian Veterinarians, pp. 97-98.
Miale, J., 1965. The fibrometer system for routine coagulation tests. Am. J. Clin. Path. 43, 475-480.

Morrisey, J.K., Paul-Murphy, J., Fialkowski, J.P., Hart, A., Darien, B.J., 2003. Estimation of prothrombin times of hispaniolan Amazon parrots (Amazona ventralis) and umbrella cockatoos (Cacutua alba). J. Avian Med. Surg. 17, 72-77.

Mount, M.E., Feldman, B.F., 1983. Mechanism of diphacinone rodenticide toxicosis in the dog and its therapeutic implications. Am. J. Vet. Res. 44, 2009-2017.

Pelfrene, A.F., 1991. Synthetic organic rodenticides. In: Hayes Jr., W.J., Laws Jr., E.R (Eds.), Handbook of Pesticide Toxicology, vol. 3: Classes of Pesticides. Academic Press, Inc., San Diego, CA, pp. 1271-1316.

Peterle, T.J., 1991. Wildlife Toxicology. Van Nostrand Reinhold, New York.

Powers, L.V., 2000. Avian hemostasis. In: Fudge, A.M. (Ed.), Laboratory Medicine: Avian and Exotic Pets. W.B. Saunders Company, Philadelphia, PA, pp. 35-45.

Primus, T.M., Goldade, D.A., Petty, E.E., Johnston, J.J., 1996. Solid-phase extraction and reversed-phase ion-pair high-performance liquid chromatographic determination of chlorophacinone and diphacinone residues in range grass. J. Chromatogr. Sci. 34, 389-393.

Rattner, B.A., Horak, K.E., Johnston, J.J., Primus, T.M., Stahl, R.S., 2009. Development of a prothrombin time clotting assay for raptors and its application for assessing risk of the anticoagulant rodenticide diphacinone. In: Proceedings of the 30th Annual Meeting of the Society of Environmental Toxicology and Chemistry-North America. Abstract 437.

Rattner, B.A., Warner, S.E., Day, D.D., Horak, K.E., Johnston, J.J., 2010. Acute toxicity of diphacinone to the American kestrel (Falco sparverius): effects on surviva and blood clotting time. In: Proceedings of the 24th Vertebrate Pest Conference, Abstract 68.

Savarie, P.J., Hayes, D.J., McBride, R.T., Roberts, J.D., 1979. Efficacy and safety of diphacinone as a predacide. In: Kenaga, E.E. (Ed.), Avian and Mammalian Wildlife Toxicology, ASTM STP 693. American Society for Testing Materials, pp. 69-79.

Shlosberg, A., Booth, L., 2006. Veterinary and clinical treatment of vertebrate pesticide poisoning-a technical review, Landcare Research. Lincoln, New Zealand.

Spinler, S.A., Nutescu, E.A., Smythe, M.A., Wittkowsky, A.K., 2005. Anticoagulation monitoring, Part 1: warfarin and parenteral direct thrombin inhibitors. Ann. Pharmacother. 39, 1049-1055.

Stone, W.B., Okoniewski, J.C., Stedelin, J.R., 1999. Poisoning of wildlife with anticoagulant rodenticides in New York. J. Wildl. Dis. 35, 187-193.

Stone, W.B., Okoniewski, J.C., Stedelin, J.R., 2003. Anticoagulant rodenticides and raptors: recent findings from New York, 1998-2001. Bull. Environ. Contam. Toxicol. 70, 34-40.

Stopforth, A., 1970. A study of coagulation mechanisms in domestic chickens J. Comp. Pathol. 80, 525-533.

Tahira, N., Dube, B., Agrawal, G.P., 1977. Blood coagulation studies in some wild Indian birds: effects of different tissue thromboplastins. J. Comp. Path. 87 451-457.

Thomson, A.E., Squires, E.J., Gentry, P.A., 2002. Assessment of factor V, VII and $\mathrm{X}$ activities, the key coagulant proteins of the tissue factor pathway in poultry plasma. Br. Poultry Sci. 43, 313-321.

Timms, L. 1977. The estimation of prothrombin time of chickens and turkey plasma using a phenol-saline thromboplastin or Russell Viper venom. Br. Vet. J. 133, 623-628.

Triplett, D.A., Harms, C.S., 1981a. Russell's Viper venom time, In: Procedures for the Coagulation Laboratory. Educational Products Division. American Society of Clinical Pathologists, Chicago, IL pp. 15-16.

Triplett, D.A., Harms, C.S., 1981b. Thrombin clotting time, In: Procedures for the Coagulation Laboratory. Educational Products Division. American Society of Clinical Pathologists, Chicago, IL, pp. 20-21.

US EPA, 1998. Reregistration Eligibility Decision (RED): Rodenticide Cluster EPA 738-R-98-007. Washington, DC. 〈http://www.epa.gov/oppsrrd1/REDs/ 2100red.pdf $>$.

US EPA, 2008. Final Risk Mitigation Decision for Ten Rodenticides. 〈http://www. epa.gov/pesticides/reregistration/rodenticides/finalriskdecision.htm $\rangle$.

Veltmann Jr., J.R., Ross, E., Olbrich, S.E., 1981. The physiological effects of feeding warfarin to poultry. Poultry Sci. 60, 2603-2611.

Walker, L.A., Turk, A., Long, S.M., Wienburg, C.L., Best, J., Shore, R.F., 2008. Second generation anticoagulant rodenticides in tawny owls (Strix aluco) from Great Britain. Sci. Total Environ. 393, 93-98.

Webster, K.H., 2009. Validation of a prothrombin time (PT) assay for assessment of brodifacoum exposure in Japanese quail and barn owls. Master's Thesis, Simon Fraser University. 